\title{
"Banking system stability: A prerequisite for financing the Sustainable Development Goals in Nigeria"
}

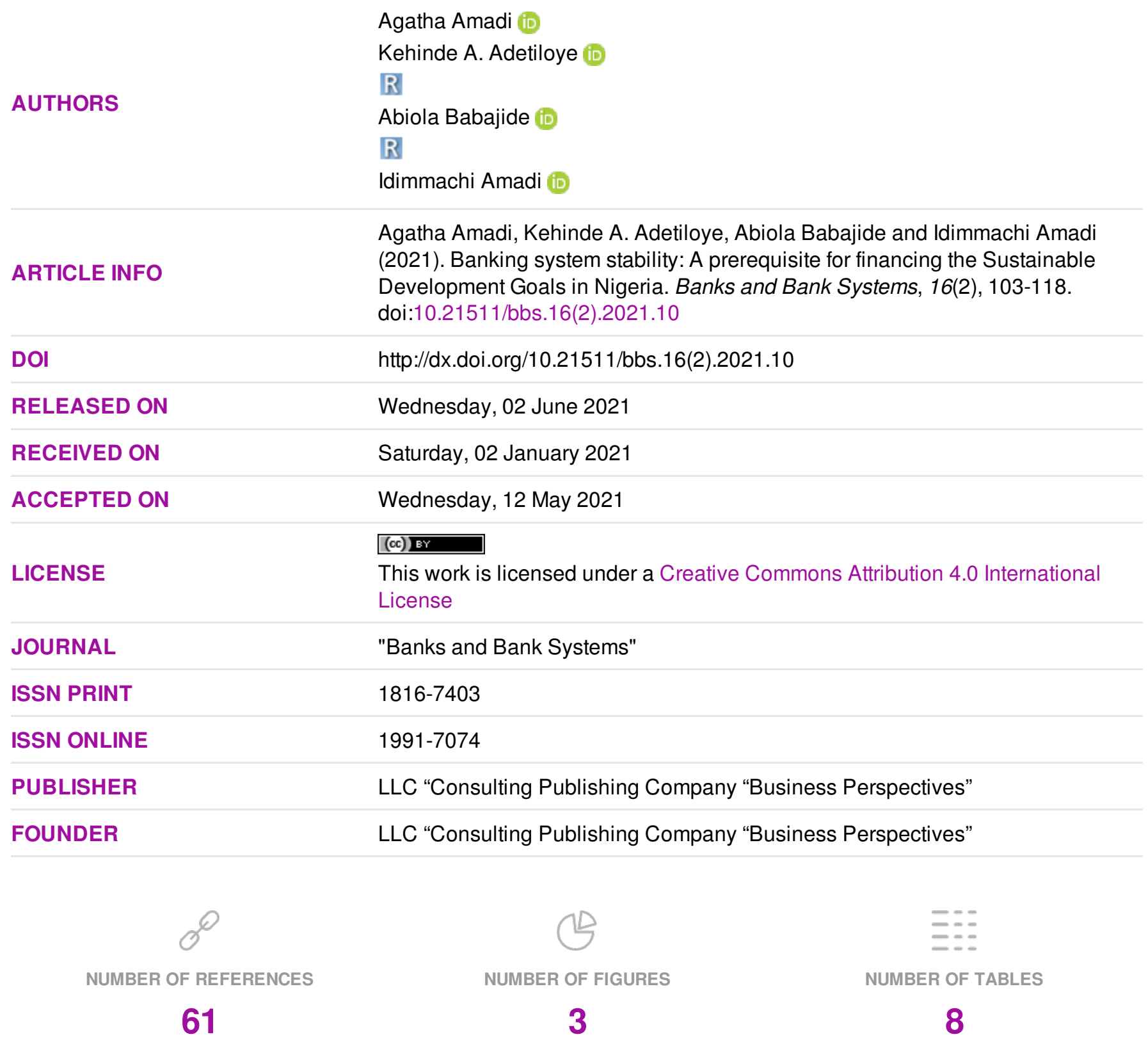

(C) The author(s) 2021. This publication is an open access article. 


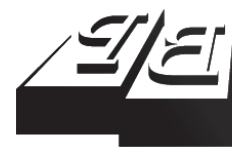

\section{BUSINESS PERSPECTIVES}

(2)

LLC "CPC "Business Perspectives"

Hryhorii Skovoroda lane, 10, Sumy, 40022, Ukraine

www.businessperspectives.org
Received on: $2^{\text {nd }}$ of January, 2021

Accepted on: $12^{\text {th }}$ of May, 2021

Published on: $2^{\text {nd }}$ of June, 2021

(c) Agatha Amadi, Kehinde Adetiloye, Abiola Babajide, Idimmachi Amadi, 2021

Agatha Amadi, Ph.D. Candidate, Faculty of Management and Social Sciences, Department of Banking and Finance, Covenant University, Nigeria. (Corresponding author)

Kehinde Adetiloye, Associate Professor Faculty of Management and Social Sciences, Department of Banking and Finance, Covenant University, Nigeria.

Abiola Babajide, Associate Professor, Faculty of Management and Social Sciences, Department of Banking and Finance, Covenant University, Nigeria.

Idimmachi Amadi, BSc Candidate, Faculty of Management and Social Sciences, Department of Economics and Development Studies, Covenant University, Nigeria.
Agatha Amadi (Nigeria), Kehinde Adetiloye (Nigeria), Abiola Babajide (Nigeria), Idimmachi Amadi (Nigeria)

\section{BANKING SYSTEM STABILITY:} A PREREQUISITE FOR FINANCING THE SUSTAINABLE DEVELOPMENT GOALS IN NIGERIA

\begin{abstract}
The banking system, which has been the fulcrum of funding for Nigeria's economy, is plagued by instability in the face of a growing amount of non-performing loans. This is examined in the current milieu of the need for funding the Sustainable Development Goals (SDGs). Using a number of proxies for SDGs 8 and 9, annual time series data covering 1992 to 2019 were used with variables such as GDP per capita, commercial banks' loans to small-scale enterprises, banking system stability indicators and liquid assets to total assets of banks. The study utilized the Autoregressive Distributed Lag. Findings showed that banking system stability has a significant positive effect on funding the SDGs 8 and 9 beyond the five per cent level of significance within the study period. Non-performing loans remained negative throughout the study. The result suggests that banking stability would enhance funding of the SDGs, and banks would be stable if they finance the SDGs. The policy implication explains the importance of banks actively pursuing opportunities to build sustainable enterprises and developing strategies that will enable their core banking business to be more venture-driven rather than consumer-oriented. In conclusion, there is a need to completely eliminate or reduce the quantum of non-performing loans from the system and establish a regulatory framework that will facilitate its expected role of intermediation in the economy profitably and successfully.
\end{abstract}

\section{Keywords}

credit to the private sector, non-performing loans (NPLs), total deposits, loans, bank funding

\section{JEL Classification $\quad$ G21, O16, O47}

\section{INTRODUCTION}

The banking system in Nigeria continues to experience unimpressive and unstable financial conditions, mainly due to the hugely increasing portfolio of non-performing loans (NPLs), which is transferred from one year to another and written off without sufficient recovery efforts (Oleribe \& Taylor-Robinson, 2016). This leads to capital and shareholders' fund (SHF) erosion, impairment of liquidity, poor asset quality and consequent reduction in profitability and solvency levels. These conditions have consequently necessitated the monetary authorities initiating several banking reforms aimed at addressing the problems of unstable and unsound banks in the country. According to Bebeji (2013), despite several banking reforms in Nigeria, the problems of banking instability caused by non-performing loans seem endless as the soundness of more banks continues to be threatened, so that near failure and collapse would have been recorded had it not been for the Central Bank's intervention. The case of Polaris (former Skye) Bank is instructive where the Central Bank of Nigeria (CBN) had to finance up to the tune of 700 billion (about USD 2 billion) to keep it from failing. 
Antoniades et al. (2019) confirmed that the main contributors to the financial crunch experienced by the banking system in Nigeria were non-adherence to prudential guidelines, incorrect financial policy and extreme risk-taking. Although the assumption is that the banking system flourishes and survives more on risk-taking, the risks faced by banks must be efficiently managed to prevent failure and collapse (Enders \& Remig, 2014; Grober, 2007). However, stability in the banking system is attained when the banking system has the ability to withstand shocks arising from internal and external economic imbalances or any kind of volatility in their business operations.

The financial system regulators are aware of the overwhelming negative consequences of loss of confidence in the banking system (Ingves, 2016; Thomson, 1992). Hence, regulators worldwide rate banking stability as a top supervisory and regulatory policy objective. Perhaps, after South Africa and Egypt, Nigeria is next with a growing banking sector in Africa. Unlike the developed economies, significant issues in the literature that are often underreported are the factors that determine the banking system stability in emerging economies, owing to the fact that developed economies have more sophisticated financial structures than those economies yet to mature (Ozili, 2018, 2019; Okey et al., 2019).

The Sustainable Development Goals agenda was fully incorporated into the economic and environmental sustainability agenda, alongside the aspirations for progressive societies. The SDGs are more committed and ambitious, in particular in seeking to eradicate rather than diminish hunger, poverty and as a world-wide agenda. The 17 SDGs are to be nationally owned and are already universally accepted (Jeucken, 2001). There is also a great deal of energy and momentum surrounding the achievement of these goals with national ownership and a will to bring together the public sector (government), private sector, civil society and individuals to achieve the goals with financing targets.

While the public capital is scarce in supply, private finance is constrained by uncertainty, and risk and return requirements. There is a need for serious improvement of managing financial complexities of banks (Nwachukwu, 2014; Soludo, 2004). Furthermore, the banking system through its intermediation role can mobilize funds that account for part of the investment and funding the SDGs (Ziolo et al., 2018). The questions are: Do banks see or understand their role in the financing need for the accomplishment of the SDG objectives? Will the hostile business environments hinder banks from effectively carrying out this funding responsibility? How will the regulatory authorities ensure that complying with this funding role will not lead to infringement of the regulatory requirements? Finally, are deposit money banks (DMBs) in Nigeria ready to finance SDGs?

The answers to the outlined queries are key for effective development of the strategies that will ensure a sound and sustained banking system and ensure a successful and efficient mobilization of adequate capital that will be used in financing SDGs throughout its duration without a threat to the system. Generally, only about $48 \%$ of SDGs investment requirements can actually be covered in emerging economies. For example, in 2016, Multilateral Development Banks (MDBs) reportedly mobilized a total of USD163.6 billion in private co-funding with low-income economies representing 4\% (USD 5.9 billion). Middle-income economies were a significant amount of 40\% (USD 65.2 billion), while high-income economies alone represent $56 \%$, (USD 92.5 billion). The estimate revealed that the funding gap is above USD 2.5 trillion for all emerging economies and about USD 1.3 trillion specifically for African countries (Adams, 2017; Bordon \& Schmitz, 2015; Akintoye \& Opeyemi, 2014; Jaiyesimi, 2016; Kharas et al., 2014; Haigh, 2012; Jeucken, 2001). This study aims to contribute to the achievement of the Sustainable Development Goals, especially SDGs 8 and 9, in Nigeria by demonstrating the ability of the banking system, through their intermediation role, to finance the SDGs while maintaining the required level of stability and soundness. 


\section{LITERATURE REVIEW}

The stability of the banking system connotes a system that is at its upmost performance level and functions without being impaired or degraded by disruptions or volatility from its external and/ or internal environment (Adams, 2017). Besides, banking stability is mostly considered a continuum, especially in terms of being consistent with multiple combinations of the fundamental elements of finance (Novotny-Farkas, 2016). Globally, the investment required to attain the SDGs are huge, with the majority of the emerging economies, specifically because of their poor infrastructural development, thereby, making the scale of existing financial flows insufficient (Pisano et al., 2012; Sadiq \& Mushtaq, 2015). The only channel for closing the resulting funding gap for the attainment of SDGs' objectives is via a sustained stability in the banking system, which will be able to provide and stand the pressure of finance requirements (Stenberg et al., 2017; Weber, 2014).

\subsection{Stability and sustainability of the banking system towards funding the SDGs}

Banks implement sustainable banking in two facets: daily internal operations (management of their risks and exposures, opportunities, costs and the branch operations) and external relations with their customers, investors, funding of projects, etc. (Wiek \& Weber, 2014). A survey revealed that less than a quarter of banks in Nigeria had low engagement with sustainable banking principles while the others have none (Ahmed et al., 2015). To show their commitment, the banks highlight the sustainable banking principles on public domains and platforms (Antoniades et al., 2019). Supranational financial bodies have identified threats to the stability of the banking system and have taken several approaches to minimize their potential adverse impacts on the system. In 2001, the Basel Committee on Banking Supervision introduced "Know Your Customer" as critical to protecting the soundness, integrity and safety of banking systems (Akintoye \& Opeyemi, 2014; Egharevba, 2007). Such a banking system would guarantee a sustainable and reliable financial intermediation, as well as have the capacity to provide access to credit and payment systems to its customers, help businesses and household to transfer financial resources and would contribute to the continuous economic growth and sustainable development of the economy (Duffie, 2019; Babajide \& Olokoyo, 2017). Due to the economic recession episodes that the country experienced within the last three decades, the fragility of her financial and banking system has been brought to fore of public discourse by policy makers, regulators and academics (Adeleye et al., 2018).

This study complements previous literature on banking system stability and SDGs by throwing more light on the interaction between the stability of the banking system and funding of the SDGs. New knowledge and understanding in this area of research is of great interest, since previous literature on financing SDGs were mainly on developed economies (Noor \& Pickup, 2017; Pisano et al., 2012; Kharas et al., 2014), while emerging economies are neglected. Therefore, this study fills the gap by examining the link between banking stability and financing the SDGs in an emerging economy. In addition to the fact that there is dearth of literature on the association between banking stability and financing sustainable development goals in Nigeria, some literature focused on sustainable finance (Haigh, 2012) and not how to raise or mobilize capital to fund the SDGs. This is very interesting to note because the existing literature (for instance, Osabohien et al., 2020; Oleribe \& Taylor-Robinson, 2016; Nwachukwu, 2014) highlighted financing individual SDGs but failed to examine where to access funding that will enable the successful achievement of SDGs by 2030 . In the light of the above, it becomes necessary and important to examine to what extent the banking system is able to sustainably support the funding of the SDGs while maintaining the required stability, and in the process of testing the capacity and strength of the banking system. However, financing the banks themselves to perform this task presents specific and pertinent issues (Eke et al., 2020).

\subsection{The link between the banking system and the SDGs}

The SGDs of interest to this study are 8 and 9. SDG 8 is particularly concerned with the funding of the real economy for at least $7 \%$ growth 


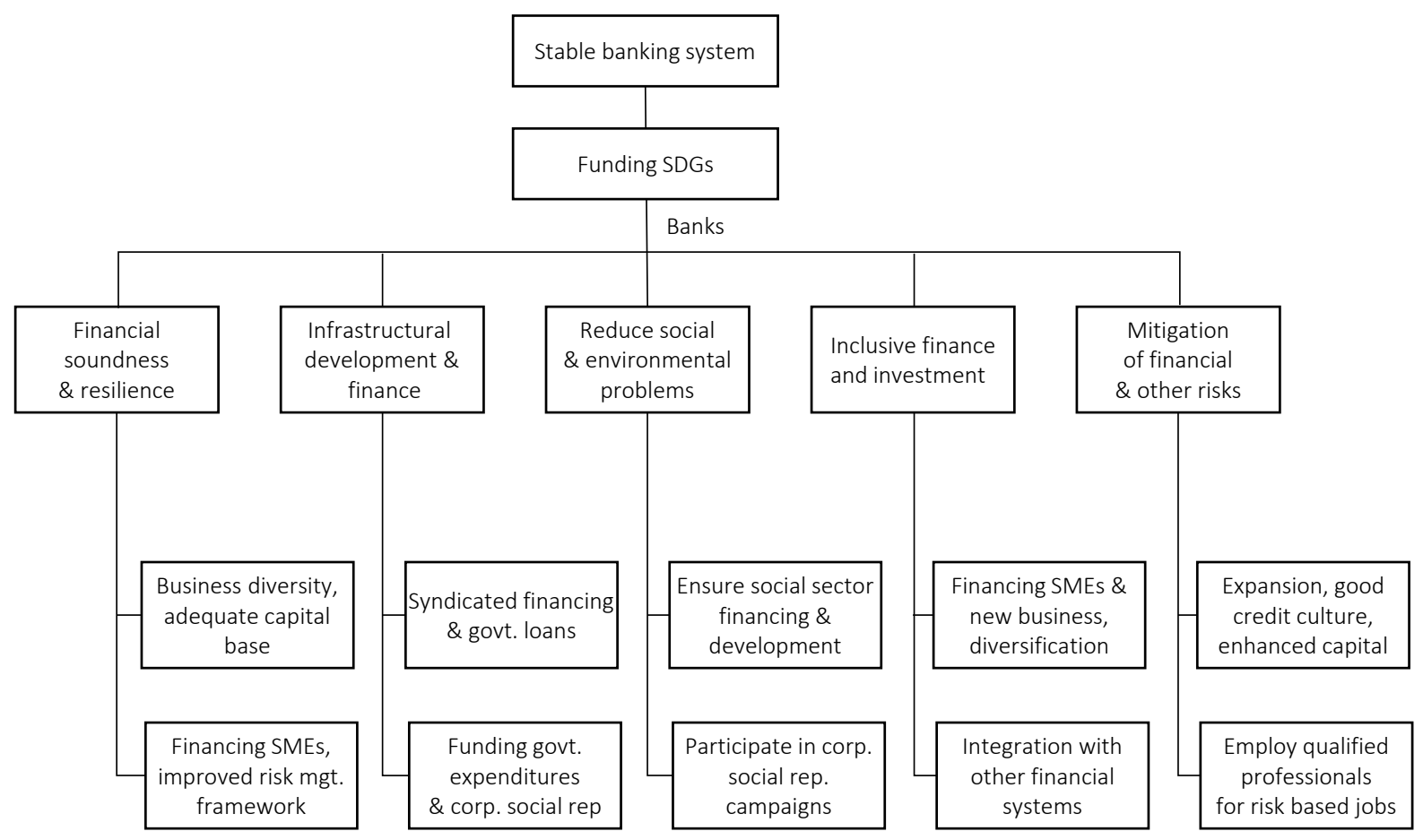

Figure 1. A stable banking system and SDG funding framework

with full productive employment that emphasizes real growth rate for an employed person. SDG 9 focuses on infrastructure development, innovation and industrialization. Banks need to tune up to be sustainably involved in SDG 9 as they have been involved in SDG 8 as matter of practice. However, three key aspects are noticeable in the link between sustainable development and the banking system. The first involves the environmental regulations introduced that affect the banking system in several ways. The second issue concerns credit risk management over which the-banking system has continued to be reactive rather than proactive regarding challenges with respect to non-performing loans growth. The third is with respect to the stakeholders' pressures as it deals with the bank's reputational risk (Baranes, 2009; Egede \& Lee, 2007; Thompson \& Cowton, 2004).

Figure 1 provides a framework for a stable banking system and SDG funding, showing key operational activities in which banks must be involved consistently to remain sustainable in order to successfully provide sufficient funding for the SDGs up to 2030.

\subsection{Review of the empirical literature}

The first discussion is on banking stability, while the second is on funding the SDGs. Dwumfour (2017) examined banking stability in sub-Saharan Africa. Using $Z$-score to proxy stability, the result showed that crisis and high percentage of foreign banks reduce bank stability, while diversification positively affects stability. The results support largely the competition-fragility view. Therefore, the less the competition amongst banks during crises periods, the more banks achieve stability. Similarly, Ozili (2019) used aggregate data to analyze the determinants of banking stability. The result revealed that the level of non-performing loans, bank efficiency and regulatory capital are the major determinants of banking stability in Nigeria. Toader et al. (2018) studied the influence of corruption on banking stability in European emerging markets. The result indicates that lower levels of corruption impact positively bank stability leading to reduced credit losses with more realistic credit growth. The result showed further that the stability of banks operating in the countries that have not adopted corporate governance have higher impact of corruption. In addition, Sere- 
Ejembi et al. (2014) adopted a combination of various macro-fundamentals and financial soundness indicators after constructing a banking system stability index (BSSI) for Nigeria. The findings showed that banking system stability indicators (BSSI) could act as an early warning sign to indicate fragility of the banks that could be used as a complimentary regulatory policy instrument for detecting potential threat to the banking system.

In terms of funding the SDGs, Ziolo et al. (2018) examined financial stability and how SDGs can be financed. The result showed that SDG funding is not short-term but a sophisticated and long-term product that is determined by various economic and non-economic elements. The study further revealed that the choice of a particular source of finance and instruments impacts both the efficiency of public expenditure and the stability of the economic system.

Furthermore, Sadiq and Mushtaq (2015) investigated major roles Islamic finance play in achieving the SDGs. Findings showed that from financial stability viewpoint, there is a need for the financial system to focus more on generating organizational diversity, switch to portfolios with higher amounts of equity-based funding and establishment of new equity-based financing institutions. Weber et al. (2010) investigated the role played by environmental orientation and sustainability in managing commercial bank risks. The result showed that sustainability could be used as a measure to forecast a debtor's financial performance and enhance the rating predictive validity. Similarly, Usman and Tasmin (2016) analyzed the importance of Islamic micro-finance for achieving the SDGs. The result showed that Islamic micro-financing has the potential to develop human capital towards empowering self-reliance, social cohesion knowledge and skill acquisition. Adetiloye et al. (2020) and Kharas et al. (2014) investigated financing the post-2015 SDGs. The study grouped the global development finance sources into three groups, namely: public finance, private finance and concessional public funding. The results showed that financing the SDGs should be better at a country level. There has been ample research on SDGs throughout the literature, but few refer to any developing country in detail. This is what is attempted in this study.

\section{RESEARCH METHODS}

The stability of the banking system is measured as a composite index, derived from a standardized process and weighted mean of three indices, which includes sub-index of economic climate, banking soundness and bank vulnerability to externalities (Cheang \& Choy, 2010). Novotny-Farkas (2016) and Sere-Ejembi et al. (2014) reported certain stability indicators that were used to construct a Banking System Stability Indicators (BSSI) based on the framework of the International Monetary Fund-Financial Stability Indicators (IMF-FSIs). This study employed some of these BSSI indicators to proxy banking system stability covering the period of 1992 to 2019. The period chosen allows the testing of the capacity of the banking system for a reasonable length of time for resilience to fund the SDGs. The variables used for measuring both the banking stability index and SDGs (8 and 9) were sourced from the World Development indicators (WDI) database.

Table 1. Description of variables, proxies, justification and a priori

Sources: Authors' compilation (2020).

\begin{tabular}{|c|c|c|}
\hline $\begin{array}{l}\text { Description of } \\
\text { variables }\end{array}$ & Literature support & A priori \\
\hline GDPPC - GDP per capita & Carree et al. (2007) & $>0$ \\
\hline $\begin{array}{l}\text { CBLSE - Commercial } \\
\text { Banks Loans to Small } \\
\text { Scale Enterprises }\end{array}$ & $\begin{array}{l}\text { Oke and Aluko (2015), } \\
\text { Aliyu and Bello (2013) }\end{array}$ & $>0$ \\
\hline $\begin{array}{l}\text { BSSI - Banking System } \\
\text { Stability Indicators }\end{array}$ & Sere-Ejembi et al. (2014) & $>0$ \\
\hline $\begin{array}{l}\text { LATA - Liquid Assets to } \\
\text { Total Assets }\end{array}$ & Jayakumar et al. (2018) & $>0$ \\
\hline $\begin{array}{l}\text { ROA - ROA, Net income } \\
\text { to assets }\end{array}$ & $\begin{array}{l}\text { Jayakumar et al. (2018), } \\
\text { Fernández et al. (2016) }\end{array}$ & $>0$ \\
\hline $\begin{array}{l}\text { TLTD - Total Loans to } \\
\text { Total Deposits of DMBs }\end{array}$ & Jayakumar et al. (2018) & $>0$ \\
\hline $\begin{array}{l}\text { LCPS - Credit to Private } \\
\text { Sector }\end{array}$ & Akinlo \& Oni (2015) & $>0$ \\
\hline $\begin{array}{l}\text { FND - Financial } \\
\text { Deepening }\end{array}$ & Olawumi et al. (2017) & $>0$ \\
\hline $\begin{array}{l}\text { TNTL - Total Non- } \\
\text { Performing Loans to } \\
\text { Total gross Loans of } \\
\text { DMBs }\end{array}$ & Shijaku (2016) & $>0$ \\
\hline $\begin{array}{l}\text { EATA - External Assets } \\
\text { to Total Assets }\end{array}$ & $\begin{array}{l}\text { Jayakumar et al. (2018), } \\
\text { Sere-Ejembi et al. (2014) }\end{array}$ & $>0$ \\
\hline
\end{tabular}

The study was estimated using an Autoregressive Distributed Lag (ARDL) model developed by Pesaran et al. (2001) and Pesaran and Shin (1998). ARDL is used mainly where the combination of 
variables are stationary at both levels $\mathrm{I}(0)$ and first difference I(1). ADF unit root tests for stationarity of the variables validates the submissions by Kutosoyiannis (1997) and Johansen (1991) that time series data have unit root. The study used the Breusch-Pagan test as a post valuation test to assess the degree of variation and level of freedom among the regressors, while the parameter stability test was used to check the suitability of a well-detailed ARDL model. Derivation of banking system stability index for Nigeria was adopted following Sere-Ejembi et al. (2014).

$$
\begin{aligned}
& B S S I_{t}=\omega_{1} B S I_{t}+\omega_{2} B V I_{t}+\omega_{3} E C I V I_{t}, \\
& \sum_{p=1}^{3} \omega_{p}=1,
\end{aligned}
$$

where $\omega_{p}$ - weight attached to a single sub-index indicating its comparative importance.

Statistical normalization transforms the indicators to a mutual scale with a zero mean, and its standard deviation equals one. The standard deviation is the scaling factor, and the model is as shown below. Using the statistical method, the BSSI is obtained by computing the weighted averages of the three sub-indices that emerged from the normalization process, namely:

$$
Z_{t}=\left(\frac{X_{t}-\mu}{\sigma}\right)
$$

where $X_{t}$ depicts the value of the indicators $(X)$ during the period $t, \mu$ represents the mean, and $\sigma$ indicates the standard deviation.

The BSSI is developed through weighting:

$$
\begin{aligned}
& B S S I_{t}=\omega_{s} \sum_{i=1}^{8} \theta_{s i} z_{t s}+\omega_{v} \sum_{i=1}^{7} \theta_{v i} z_{t v}+ \\
& +\omega_{3} \sum_{i=1}^{3} \theta_{c i} z_{t c} \\
& \sum_{p r=s, v, c} \omega_{r}=1
\end{aligned}
$$

where $z_{\text {tr }}$ represents values of the banking stability indicators that are statistically normalized; $s$ connects to the BSSI, while $c$ refers to ECI and $v$ refers to BVI. The weight of the individual statistically normalized indicator in each sub-index:

$$
\theta_{r i}=\frac{\mu_{i}}{\sum_{i=1}^{U} \mu_{i}},
$$

where $r=\{s, v, c\} ; \mu_{i}$ represents responses that reverted high in during the consolidated responses from $U$ and FGD, which depicts the correct number of indicators in each sub-index.

Thus:

$$
\begin{aligned}
& B S S I_{t}=\sum_{i=1}^{8} \theta_{s i} z_{t s}, \\
& B V I_{t}=\sum_{i=1}^{7} \theta_{v i} z_{t v}, \\
& B C I_{t}=\sum_{i=1}^{3} \theta_{s i} z_{t s} .
\end{aligned}
$$

The adapted model is stated as follows:

$$
S D G s_{i t} 8 \& 9=B S S I
$$

$S D G s_{i t} 8 \& 9=$

$=f($ Banking System Stability Indicators $)$,

$S D G s_{i t} 8 \& 9=G D P P C_{i t}+C B L S E_{i t}+$

$f(L A T A+L A T A+R O A+$

$+T L T D+T N T L+E A T A)$,

$G D P P C_{i t}=\alpha_{1}+\beta_{1} L A T A_{i t}+\beta_{2} R O A_{i t}+$ $+\beta_{3} T_{L T D_{i t}}+\beta_{4} T N T L_{i t}+\beta_{5} E A T A_{i t}+\varepsilon_{i t}$,

$C B L S E_{i t}=\alpha_{2}+\beta_{1} L A T A_{i t}+\beta_{2} R O A_{i t}+$

$+\beta_{3}$ TLTD $_{i t}+\beta_{4}$ TNTL $_{i t}+\beta_{5}$ EATA $_{i t}+\varepsilon_{i t}$,

Following Pesaran and Shin (1998) we specify the unrestricted $[\mathrm{ECM}(-1)]$ as thus;

$\Delta G D P P C_{t-1}=\beta_{0}+\sum_{i=1}^{p} \beta_{1} \Delta G D P P C_{t-1}+$
$+\sum_{i=1}^{p} \beta_{2} \Delta Y_{t-1}+\beta_{1} G D P P C_{i t}+\beta_{2} Y_{t-1}+\varepsilon_{i t}$,

$\Delta C B L S E_{t-1}=\beta_{0}+\sum_{i=1}^{p} \beta_{1} \Delta C B L S E_{t-1}+$

$+\sum_{i=1}^{p} \beta_{2} \Delta Y_{t-1}+\beta_{1} C B L S E_{i t}+\beta_{2} Y_{t-1}+\varepsilon_{i t}$, 
where GDPPC and CBLSE (the indicators of SDGs) represent the dependent variable vector, $Y$ denotes the regressors (the banking system stability indicators), $p$ implies the lagged structure, $\Delta$ represents the variation in terms, $\beta_{1}$ and $\beta_{2}$ indicate the long-run coefficients, $\alpha_{1}$ and $\alpha_{2}$ are the short-run coefficients, and $\varepsilon_{t}$ represents the stochastic error term.

Explicitly, the models are estimated as follows:

$$
\begin{aligned}
& \Delta G D P P C_{t-1}=\beta_{0}+\sum_{i=1}^{p} \phi_{J} \Delta \text { LATA }_{t-1}+ \\
& +\sum_{i=1}^{p} \lambda_{J} \Delta R O A_{t-1}+\sum_{i=1}^{p} \alpha_{J} \Delta T L T D_{t-1}+ \\
& +\sum_{i=1}^{p} \sigma_{J} \Delta T N T_{t-1}+\sum_{i=1}^{p} \partial_{J} \Delta E A T A_{t-1}+\varepsilon_{i t}, \\
& \Delta C B L S E_{t-1}=\beta_{0}+\sum_{i=1}^{p} \phi_{J} \Delta \text { LATA }_{t-1}+ \\
& +\sum_{i=1}^{p} \ddot{\mathrm{e}}_{J} \Delta R O A_{t-1}+\sum_{i=1}^{p} \mathrm{a}_{J} \Delta T L T D_{t-1}+ \\
& +\sum_{i=1}^{p} \sigma_{J} \Delta T N T_{t-1}+\sum_{i=1}^{p} \partial_{J} \Delta E A T A_{t-1}+\varepsilon_{i t},
\end{aligned}
$$

where $\Delta$ indicates the first-difference operator and $p$ is the maximum lag order. The existence of co-integration amongst variables is tested using the F-statistics. The coefficients: $\phi, \sigma, \alpha, \lambda, \beta, \partial$ and $\alpha$ that match the dynamic forces of the short-run model, however $\delta_{1}, \delta_{2}, \delta_{3}, \delta_{4}$, and $\delta_{5}$ represent the long-run association.

Hence, $H_{0}: \quad \delta_{1}=\delta_{2}=\delta_{3}=\delta_{4}=\delta_{5}=0$ (shows the null hypothesis, of nonexistence of a long-run association between the variables used in this study).

However, $H_{1}: \quad \delta_{1} \neq \delta_{2} \neq \delta_{3} \neq \delta_{4} \neq \delta_{5} \neq 0$ (shows the alternative hypothesis of a long-run link amongst the variables).

Therefore, as co-integration is present, long-run measurement will be determined, which is stated as:

$$
\begin{aligned}
& G D P P C_{i t}=\beta_{0}+\delta_{1} L A T A_{i t}+\delta_{2} R O A_{i t}+ \\
& +\delta_{3} T L T D_{i t}+\delta_{4} T L T D_{i t}+\delta_{5} E A T A_{i t}+\varepsilon_{i t},
\end{aligned}
$$

$$
\begin{aligned}
& C B L S E_{i t}=\beta_{0}+\delta_{1} L A T A_{i t}+\delta_{2} R O A_{i t}+ \\
& +\delta_{3} T L T D_{i t}+\delta_{4} T L T D_{i t}+\delta_{5} E A T A_{i t}+\varepsilon_{i t} .
\end{aligned}
$$

In an effort to identify the correct ARDL model, Liew (2004) used a selection lag criterion, the Akaike Information Criterion. According to Liew (2004), this type of information criterion could be used if the sample size is below 60. This is a maximum lag of 2 as established by Pesaran et al. (1999). After this, the study models the short-run equations derived from the ECM:

$$
\begin{aligned}
& \Delta G D P P C_{t-1}=\beta_{0}+\sum_{i=1}^{p} \phi_{J} \Delta L^{\prime} A T A_{t-1}+ \\
& +\sum_{i=1}^{p} \lambda_{J} \Delta R O A_{t-1}+\sum_{i=1}^{p} \alpha_{J} \Delta T L T D_{t-1}+ \\
& +\sum_{i=1}^{p} \sigma_{J} \Delta T N T_{t-1}+\sum_{i=1}^{p} \partial_{J} \Delta E A T A_{t-1}+\varepsilon_{i t},
\end{aligned}
$$

$$
\begin{aligned}
& \Delta C B L S E_{t-1}=\beta_{0}+\sum_{i=1}^{p} \phi_{J} \Delta L A T A_{t-1}+ \\
& +\sum_{i=1}^{p} \lambda_{J} \Delta R O A_{t-1}+\sum_{i=1}^{p} \alpha_{J} \Delta T L T D_{t-1}+ \\
& +\sum_{i=1}^{p} \sigma_{J} \Delta T N T_{t-1}+\sum_{i=1}^{p} \partial_{J} \Delta E A T A_{t-1}+\varepsilon_{i t} .
\end{aligned}
$$

The short-run model coefficients are usually constants that explain the underlying forces of the model and highlight meeting point of the model at $\partial$. This indicates that the re-parameterization of errors generated at a specific period is corrected in a subsequent period, while the long-run association tests will be inconclusive where $F$ statistic lies between the upper and lower bounds.

\section{RESULTS AND EMPIRICAL ANALYSIS}

\subsection{Data description and estimation methods}

The study used annual time series data capturing the domestic and global financial crisis, including several periods of structural reforms in Nigeria. 
Table 2. List of variables and descriptive statistics

Source: Authors' computation (2020)

\begin{tabular}{l|c|c|c|c|c}
\hline \multicolumn{1}{c|}{ Variables } & Mean & Std. dev. & Max. & Min. & Median \\
\hline LCBLSE & 10.23530 & 0.674324 & 11.40952 & 9.282464 & 10.26995 \\
\hline GDPPC & 1.780077 & 3.689517 & 12.45747 & -4.457078 & 2.222482 \\
\hdashline LATA & 0.115593 & 0.040467 & 0.177879 & 0.029778 & 0.115593 \\
\hline EATA & 0.102399 & 0.031513 & 0.189361 & 0.055657 & 0.102399 \\
ROA & 0.022421 & 0.024850 & 0.084215 & -0.022192 & 0.018391 \\
\hline TLTD & 0.226366 & 0.256830 & 0.980000 & 0.109000 & 0.226366 \\
\hline LCPS & 7.682186 & 1.931792 & 10.12354 & 4.062561 & 7.626611 \\
FND & 16.78277 & 5.360881 & 25.15527 & 9.151674 & 15.11082 \\
TNTL & 17.75143 & 4.405631 & 24.05000 & 10.76000 & 18.33000 \\
\hline
\end{tabular}

Table 2 represents the descriptive statistics of the variables. Banks' loans to small-scale enterprises had an average growth rate of $10.24 \%$, while the average rate of growth of GDP per capita was $1.8 \%$. The mean of total non-performing loans to total gross loans and financial deepening indicate a double-digit value $-17.78 \%$ and 16.8 , which portray the linkage between bank stability and funding SDGs. The mean of credit to private sector is 7.7, while the mean values of external assets to total assets, return of assets, liquid assets to total assets and total loans to total deposits are $0.10 \%$, $0.02 \%, 0.12 \%$ and $0.23 \%$, respectively. These values are low, compared to the mean value of commer- cial banks' loans to small-scale enterprises. This indicates that banks' stability must be consistently sustainable in order to provide funds needed for the SDGs.

Figure 2 depicts the annual trend data of LCBLSE and GDPPC, which are indicators of SDGs, and FND, LATA, TLTD, TNTL, LCPS, ROA and EATA, which are indicators of the banking system stability. The graphs show that the trends depict various patterns. This shows that the rate at which sustainable development was being financed cannot be said to be consistent. This trend analysis revealed a high level of variation of Nigeria's bank-
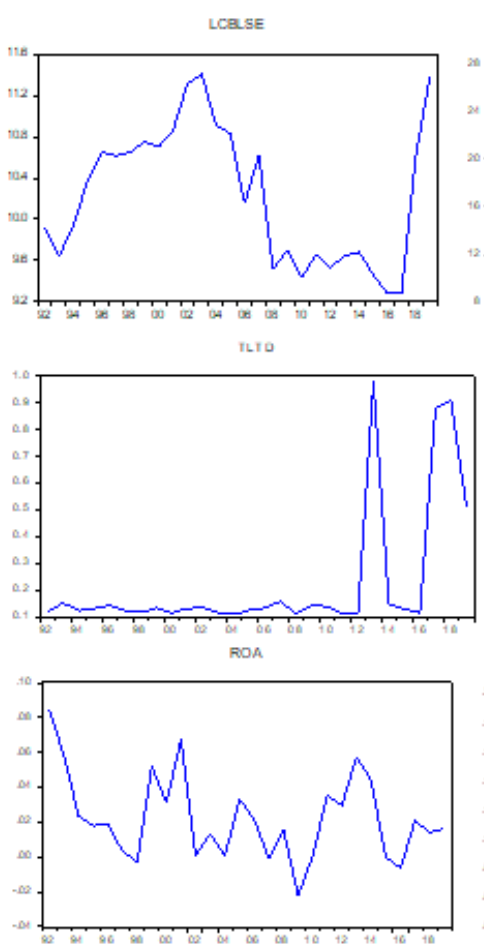
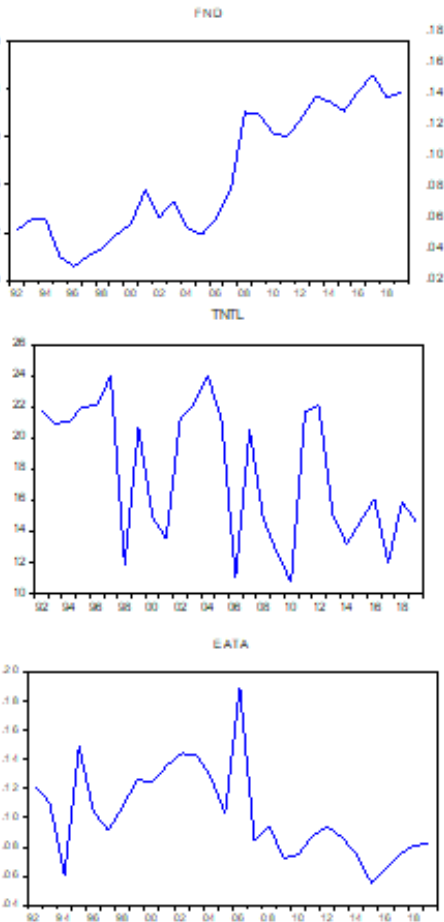

Source: Authors' computation (2020).
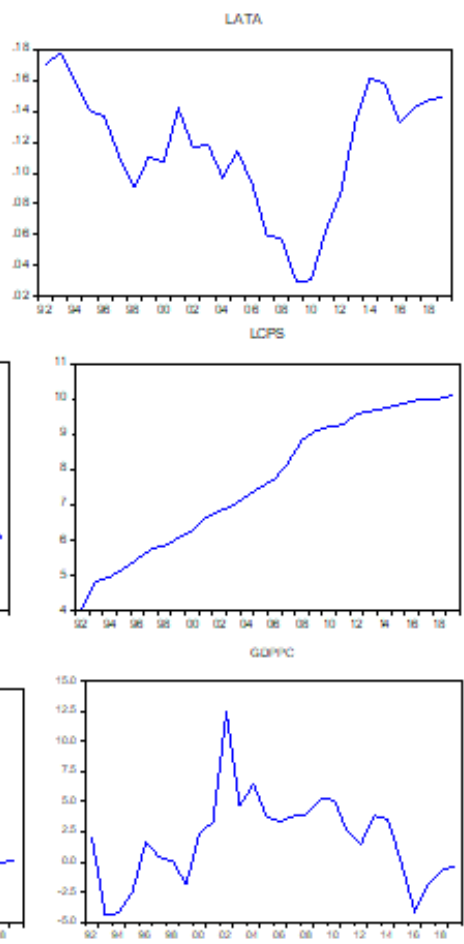

Figure 2. Trend of banking stability and SDGs 
Table 3. Correlation matrix

Source: Authors' compilation (2020).

\begin{tabular}{|c|c|c|c|c|c|c|c|c|c|}
\hline Variables & LCBLSE & GDPPC & EATA & LATA & ROA & FND & LCPS & TLTD & TNTL \\
\hline LCBLSE & 1.0000 & - & - & - & - & - & - & - & - \\
\hline GDPPC & 0.3177 & 1.0000 & - & - & - & - & - & - & - \\
\hline EATA & 0.5176 & 0.3090 & 1.0000 & - & - & - & - & - & - \\
\hline LATA & 0.0832 & -0.4755 & 0.0072 & 1.0000 & - & - & - & - & - \\
\hline $\mathrm{ROA}$ & -0.0603 & -0.1681 & 0.2500 & 0.5027 & 1.0000 & - & - & - & - \\
\hline FND & -0.3687 & 0.1325 & -0.5099 & -0.2667 & -0.3260 & 1.0000 & - & - & - \\
\hline LCPS & -0.5394 & -0.0389 & -0.6148 & -0.0803 & -0.1323 & -0.9111 & 1.0000 & - & - \\
\hline TLTD & -0.1069 & -0.1422 & -0.2688 & 0.2625 & 0.1157 & 0.5283 & 0.4602 & 1.0000 & - \\
\hline TNTL & 0.3384 & -0.0158 & 0.1875 & 0.1711 & 0.1401 & -0.3101 & -0.5080 & 0.1401 & 1.0000 \\
\hline
\end{tabular}

ing stability during the post global financial crisis of 2009 that resulted in the failure and liquidation of some Nigerian banks. The graphs show that the variation continued throughout the study period.

Table 3 shows the correlation analysis of the variables used to check the likelihood of the existence of multicollinearity in the ARDL result. The correlation coefficients result of the indicators of SDGs are in agreement with the a priori expectation.

Table 4 depicts the unit root test. The result shows that commercial banks' loans to small enterprises, gross domestic product per capita, liquid assets to total assets, total non-performing loans to total gross loans and external assets to total assets seem not to reject the null hypothesis "no stationary" at levels, whereas return on assets and total loans to total deposits were stationary at levels I $(0)$. However, after numerous re-statements on differencing and the length of lag, the series were seen to have finally rejected the null hypothesis at first difference I(1). This implies that the first difference of the series is mean reverting and stationary. Hence, commercial banks' loans to small scale enterprises, gross domestic product per capita, liquid assets to total assets, financial deepening, total non-performing loans to total gross Loans, Credit to Private Sector and external assets to total assets are integrated of order I(1). Thus, this argument stimulates the co-integration test to evaluate whether or not the linear grouping of the considered stability and SDGs indicators yields any stationary residual.

Table 5 shows the order of the ARDL models I \& II selected by AIC for the co-integration test. The results indicate that computed F-statistics for both models are higher than the upper bound critical values. Thus, the null hypotheses of no co-integration at the 5\% significance level is rejected. This supports the idea of a stable and unique long-run

Table 4. ADF unit root tests for the variables at levels and first differences

Source: Authors' compilation.

\begin{tabular}{|c|c|c|c|c|c|c|c|}
\hline \multirow[t]{2}{*}{ Variables } & $\begin{array}{c}\text { Test } \\
\text { statistics }\end{array}$ & $\begin{array}{l}\text { Critical } \\
\text { value }\end{array}$ & Remark & $\begin{array}{c}\text { Test } \\
\text { statistics }\end{array}$ & $\begin{array}{l}\text { Critical } \\
\text { value }\end{array}$ & Remark & \multirow[t]{2}{*}{$\begin{array}{c}\text { Order of } \\
\text { integration }\end{array}$} \\
\hline & \multicolumn{3}{|c|}{ At level } & \multicolumn{3}{|c|}{ At first difference } & \\
\hline LCBLSE & 1.3945 & $2.9762^{*}$ & Non stationary & $4.5502^{*}$ & $2.9810^{*}$ & Stationary & I(1) \\
\hline GDPPC & 2.4190 & $3.5875^{*}$ & Non stationary & $3.8985^{*}$ & 2.9862 & Stationary & (1) \\
\hline LATA & 1.6443 & 2.9762 & Non stationary & $4.0632 *$ & 2.9810 & Stationary & (1) \\
\hline EATA & 1.8798 & 2.9810 & Non stationary & 9.1494 & 2.9810 & Stationary & $\mathrm{I}(1)$ \\
\hline ROA & 2.9862 & $4.4096^{*}$ & Stationary & N.A & N.A & N.A & $\mathrm{I}(0)$ \\
\hline LCPS & 1.3945 & 2.9763 & Non stationary & 4.5502 & 2.9810 & Stationary & I(1) \\
\hline FND & 0.6542 & 2.9762 & Non stationary & 4.4900 & 1.9544 & Stationary & I(1) \\
\hline TLTD & -2.9980 & $3.9638^{*}$ & Stationary & N.A & N.A & N.A & $\mathrm{I}(0)$ \\
\hline TNTL & 1.5118 & 2.9980 & Non stationary & 1.9556 & $6.9017^{*}$ & Stationary & I(1) \\
\hline
\end{tabular}

Note: ${ }^{* *}$ and $*$ mean significance at $5 \%$. 
Table 5. ARDL bounds test result for co-integration relationship

Source: Authors' computation (2020)

\begin{tabular}{|c|c|c|c|c|c|c|}
\hline Dependent variables/model & \multicolumn{4}{|c|}{ Functions } & \multicolumn{2}{|c|}{$\frac{\text { F-statistics }}{76.94155^{* *}}$} \\
\hline MODEL II ARDL $(2,2,2,2,2)$ & & & & & \multicolumn{2}{|c|}{$46.33162 * *$} \\
\hline Significance level & \multicolumn{2}{|c|}{$1 \%$} & \multicolumn{2}{|c|}{$5 \%$} & \multicolumn{2}{|c|}{$10 \%$} \\
\hline Integration order & $1(0)$ & (1) & $\mathrm{I}(0)$ & $I(1)$ & $I(0)$ & $I(1)$ \\
\hline Model I - Critical bound values & 2.73 & 3.9 & 2.17 & 3.21 & 1.92 & 2.89 \\
\hline Model II - Critical bound values & 2.96 & 4.26 & 2.32 & 3.5 & 2.03 & 3.13 \\
\hline
\end{tabular}

Note: $* * * * *$ and $*$ depict rejection of null hypothesis at $1 \%, 5 \%$ and $10 \%$ significance levels, respectively.

relationship between banking stability and SDGs funding. This long-run link is in tandem with the findings of Gangi et al. (2019), Ziolo et al. (2018) and Bordon and Schmitz (2015) who reported a long-run link between banking stability and funding SDGs.

\section{DISCUSSION}

Tables 6, 7 and 8 present the long-run appraisal, the short-run analysis, and the diagnostic and stability tests. Table 6 reveals in model I that external assets to total assets, financial deepening, credit to private sector and total non-performing loans to total gross loans have a positive and significant impact on the SDG 8 funding in Nigeria at the 5\% critical level. Whereas liquid assets to total assets (proxy for SDG 9), return on assets and liquid assets to total assets bore a negative but significant influence at a 5\% critical level. Similarly, model II shows that external assets to total assets, liquid assets to total assets and credit to private sector have a positive and significant impact on SDG funding at 0.1 and 0.05 . Credit to private sector, ROA, liquid assets to total assets and total non-performing loans to total gross loans have a negative and

Table 6. Long-run tests: Model I and II significant influence on SDG funding at 0.1 and 0.05 confidence levels. Largely, this shows that $10 \%$ change in external assets to total assets, financial deepening, credit to private sector and total non-performing loans to total gross loans can positively increase SDG funding by $162.13 \%$, $0.28 \%, 0.86 \%$ and $0.20 \%$, respectively. For model II, a 10\% change in external assets to total assets, liquid assets to total assets and credit to private sector will positively improve SDGs funding by $24.12 \%, 9.63 \%$ and $0.31 \%$, respectively. This result is in line with Bordon and Schmitz (2015), Sadiq and Mushtaq (2015) and Pisano et al. (2012) that banking stability is a key factor that can drive sustainable development funding in an economy.

The direct relationship of liquid assets to total assets, return on assets and liquid assets to total assets is an indicator of banking stability, which turned out to be negative and significant for model I. In model II, return on assets, credit to private sector, liquid assets to total assets and total non-performing loans to total gross loans have a negative significant relationship with SDGs funding. The effect is that Nigeria's banking system requires a huge variety of sustainable products and a market for diversification and expansion of

Source: Authors' computation (2020).

\begin{tabular}{|c|c|c|c|c|c|c|}
\hline \multirow{2}{*}{$\begin{array}{c}\text { Variables } \\
\text { Regressors }\end{array}$} & \multicolumn{3}{|c|}{ MODEL I } & \multicolumn{3}{|c|}{ MODEL II } \\
\hline & Coefficient & t-statistics & Prob. & Coefficient & t-statistics & Prob. \\
\hline EATA & 162.1331 & 94.9392 & 0.0001 & 24.1177 & 21.6842 & 0.0021 \\
\hline FND & 0.2782 & 8.2372 & 0.0144 & -0.1236 & -6.1571 & 0.0254 \\
\hline LATA & -19.7615 & -21.9772 & 0.0021 & 9.6252 & 19.7913 & 0.0025 \\
\hline LCPS & 0.8642 & 11.7337 & 0.0072 & 0.3145 & 7.1357 & 0.0191 \\
\hline ROA & -130.9991 & -35.2487 & 0.0008 & -24.8112 & -12.5584 & 0.0063 \\
\hline TLTD & -7.3569 & -46.7042 & 0.0005 & -1.1804 & -4.2353 & 0.0515 \\
\hline TNTL & 0.2956 & 20.0656 & 0.0025 & -0.0250 & -3.01642 & 0.0946 \\
\hline
\end{tabular}


Table 7. Short-run tests: Model I and II

\begin{tabular}{|c|c|c|c|c|c|c|}
\hline \multirow{2}{*}{ Variables } & \multicolumn{3}{|c|}{ MODEL I } & \multicolumn{3}{|c|}{ MODEL II } \\
\hline & Coefficient & t-statistics & Prob. & Coefficient & t-statistics & Prob. \\
\hline c & 0.934424 & 0.274391 & 0.0000 & 1.066633 & 0.572049 & 0.0004 \\
\hline $\mathrm{D}(\mathrm{EATA})$ & 30.92438 & 7.082166 & 0.0120 & -45.51151 & 9.466897 & 0.0049 \\
\hline $\mathrm{D}(\mathrm{FND})$ & -0.386934 & 0.125572 & 0.0369 & -1.088903 & 0.177113 & 0.0017 \\
\hline $\mathrm{D}(\operatorname{LATA}(-1))$ & -45.1061 & 14.7495 & 0.0377 & 4.068103 & 39.96114 & 0.9229 \\
\hline $\mathrm{D}(\mathrm{LCPS})$ & 2.582977 & 1.569745 & 0.1752 & 34.10079 & 2.680163 & 0.0001 \\
\hline $\mathrm{D}(\mathrm{ROA})$ & -28.81657 & 14.51080 & 0.1180 & 239.5842 & 48.93090 & 0.0045 \\
\hline $\mathrm{D}(\mathrm{TLTD})$ & -2.087904 & 0.659310 & 0.0340 & 14.47029 & 1.354968 & 0.0001 \\
\hline $\mathrm{D}(\mathrm{TNTL})$ & -0.106778 & 0.037904 & 0.0480 & -0.021266 & 1.057273 & 0.7256 \\
\hline ECM(-1) & -0.76053 & 0.325071 & 0.0194 & -0.793910 & 2.67918 & 0.0492 \\
\hline $\mathrm{R}^{2}$ & 0.743322 & F-statistic & - & $R^{2}$ & 0.68289 & 13.71620 \\
\hline Adjusted $R^{2}$ & 0.697312 & Prob. (F-statistic) & - & Adjusted $R^{2}$ & 0.657312 & 0.00630 \\
\hline Log likelihood & 49.61169 & Durbin-Watson stat. & 2.0218 & Log likelihood & 51.21157 & 2.332155 \\
\hline
\end{tabular}

businesses in order to remain stable to fund the SDGs. In addition, the positive influence of FND and LCPS shows that there is a need for enabling business and operating environments that propels business development and growth to aid enhancement of Nigeria's banking stability. Thus, there is a need to drive business strategies that foster an efficient business environment that will boost the SDG agenda in Nigeria.

The short-run dynamics estimations in Table 7 shows both negative and positive associations between the lags of the regressors. The coefficient values for the $\operatorname{ECM}(-1)$ for both models infer that the result is in conformity with expectation, since it is negative and significant. The values -0.76053 and -0.793910 suggest that the speed of adjustment towards long-run equilibrium for both models are $76 \%$ and $79 \%$, respectively. This means that about $76 \%$ divergence, due to the equilibrium error in the previous year, is corrected in the next period for model I, while in model II, about $79 \%$ divergence due to the equilibrium error in the previous year is corrected in the next period. Hence, it can be established that error correction towards the long-run dynamic for both models is quick. Similarly, $\mathrm{R}^{2}$ values of 0.743322 and 0.68289 imply that each model is a good fit as over $74 \%$ and $68 \%$ variations in SDGs funding is explained by the explanatory variables in model I, while $68 \%$ of variations in SDG funding is explained by the explanatory variables in models I and II. Even where the effects of the insignificant estimators are removed, the adjusted $\mathrm{R}^{2}$ values 0.697312 and 0.657312 suggest that both models are still very good. The results also show that the ECM model is not spurious because the intercept values of 0.934424 and 1.066633 are lesser than the Durbin-Watson values of 2.021890 and 2.332155 for the models.

Table 8 and Figure 3 present the results of the stability and diagnostic tests. The estimated models passed all the diagnostic tests, which indicate that

Table 8. Diagnostic and stability tests for models I and II

Source: Authors' computation (2020).

\begin{tabular}{|c|c|c|}
\hline \multirow{2}{*}{ Test statistics } & \multicolumn{2}{|c|}{ Dependent variables } \\
\hline & $\mathbf{I}$ & II \\
\hline Serial correlation & $0.699115(0.739401)$ & $0.293395(0.983087)$ \\
\hline Normality Test & 0.272765 (0.877509) & $0.524658(0.769258)$ \\
\hline Heteroskedasticity Breusch-Pagan-Godfrey & $2.472177(0.0568)$ & $0.913114(0.5768)$ \\
\hline CUSUM & Stable & Stable \\
\hline CUSUM Q & Stable & Stable \\
\hline $\operatorname{ECM}(-)$ & $-0.0794(0.3568)^{* *}$ & $-0.3501(0.2108)^{* *}$ \\
\hline
\end{tabular}

Note: The probability values for the diagnostic and stability tests are in parentheses. 

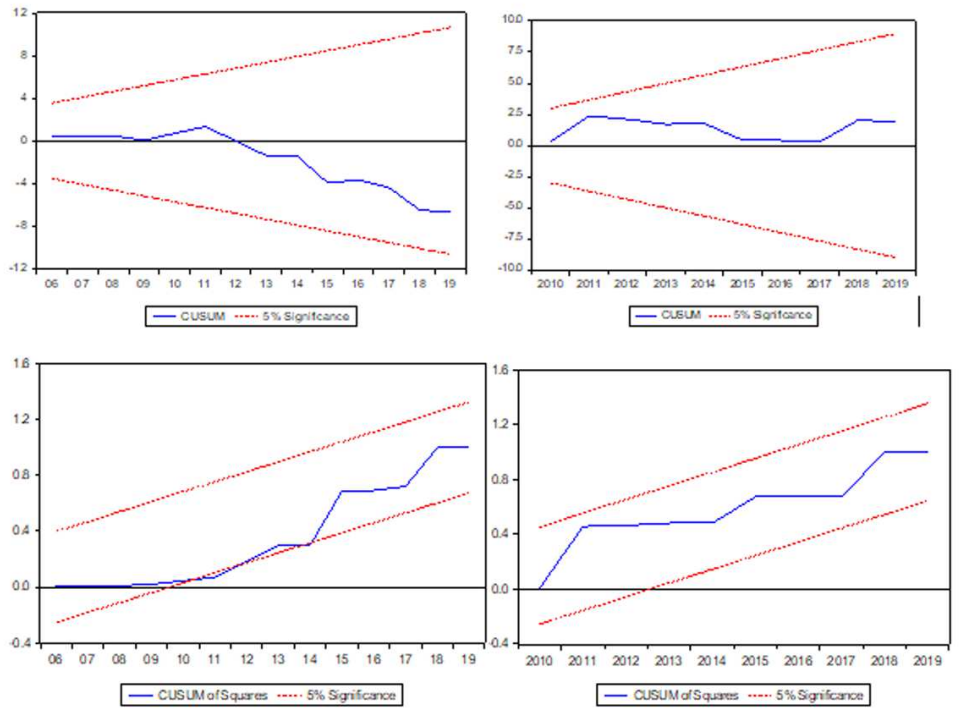

Figure 3. CUSUM and CUSUM of Squares Stability Tests - Model I and II

the error terms have similar variance and that they are uncorrelated and normally distributed. Cumulative sum of squares and cumulative re- sults fall within the critical bounds at the $5 \%$ significance level, which means that all parameters are stable over study periods.

\section{CONCLUSION AND RECOMMENDATIONS}

This paper aims to examine the ability of banks to finance key SDG areas, especially SDG 8 and 9, while maintaining the required stability. Proxies for the SDGs were credit to the private sector, loans to small businesses (for SDG 8), while total loans to total deposits were proxied for SDG9. An analysis was conducted using panel data for 1992 to 2019. The study employed a composite index derived from a standardized process and a weighted mean of three indices, including a sub-index of economic climate, banking soundness and bank vulnerability to externalities for banking system stability indicators. In addition, the panel data with two different models were analyzed using the Autoregressive Distributed Lag (ARDL). Several diagnostic and stability tests were used to confirm the results. The test results show that the banking system can contribute to the SDG funding with banking system stability achieved and sustained. Although, the effects of return on assets on its own seems not to have enhanced sustainable development funding, the extent of responsiveness of sustainable development to the variants of ROA for both models seems to be inelastic. This implies that a proportionate variation or change in Nigeria's banking system stability would lead to a more or additional proportionate change in financing SDGs. The tests revealed that banking system stability has a significant and positive link with financing SDGs. This suggests that as banking system stability improves in Nigeria, it will enhance the capacity of the banking system generally to successfully finance SDGs throughout the estimated period. Thus, the degree of bank soundness and the consistent long-term stability are important contributing factors to successful funding of SDGs in Nigeria. Based on the results of the estimation, this study concludes that banking system stability in Nigeria can enhance the funding of the SDGs and still be stable for the performance of its total intermediation functions in the economy. A novelty of these results is that despite its seeming fragility, banks can sustainably fund SDGs 8 and 9 if it can take care of non-performing loans.

This study recommends the following: First, the banking system has to actively pursue opportunities for more innovative products allowing the bank to actually create a blended or mixed value return, which 
consists of both financial and social returns through proactive search for new ways of financing and sustainable investment opportunities. Second, it should develop strategies that will allow their core banking business to be incorporated with impact investment strategies. Third, it should create organizational diversity shifting to portfolios with greater proportions of equity-based financing. This is to allow more businesses to benefit from banks' finance. This will improve and accelerate economic growth that can improve the living standards of citizens. The CBN in conjunction with the NDIC, Bankers Committee and other organizations, should create a regulatory framework that will facilitate the rapid consolidation of the banking system to successfully fulfill its role in financing the SDGs.

\section{AUTHOR CONTRIBUTIONS}

Conceptualization: Agatha Amadi, Kehinde Adetiloye, Abiola Babajide, Idimmachi Amadi.

Data curation: Agatha Amadi, Kehinde Adetiloye, Abiola Babajide, Idimmachi Amadi.

Formal analysis: Agatha Amadi, Kehinde Adetiloye, Abiola Babajide, Idimmachi Amadi.

Funding acquisition: Agatha Amadi.

Investigation: Agatha Amadi, Kehinde Adetiloye, Abiola Babajide, Idimmachi Amadi.

Methodology: Agatha Amadi, Abiola Babajide, Idimmachi Amadi.

Project administration: Agatha Amadi, Kehinde Adetiloye, Abiola Babajide.

Resources: Agatha Amadi, Kehinde Adetiloye, Abiola Babajide, Idimmachi Amadi.

Software: Kehinde Adetiloye, Idimmachi Amadi.

Supervision: Agatha Amadi, Kehinde Adetiloye, Abiola Babajide, Idimmachi Amadi.

Validation: Agatha Amadi, Kehinde Adetiloye, Abiola Babajide, Idimmachi Amadi.

Visualization: Idimmachi Amadi.

Writing - original draft: Agatha Amadi, Kehinde Adetiloye, Abiola Babajide, Idimmachi Amadi.

Writing - reviewing \& editing: Agatha Amadi, Kehinde Adetiloye, Abiola Babajide, Idimmachi Amadi.

\section{ACKNOWLEDGMENT}

The authors would like to appreciate Covenant University for financial support to publish this paper.

\section{REFERENCES}

1. Adams, C. A. (2017). The

Sustainable Development

Goals, integrated thinking and the integrated report. Glasgow: Institute of Chartered Accountants of Scotland. Retrieved from https://integratedreporting.org/wp-content/ uploads/2017/09/SDGs-and-theintegrated-report_full17.pdf

2. Adeleye, I., Ngwu, F., Iheanachor, N., Esho, E., Oji, C., OnajiBenson, T., \& Ogbechie, C. (2018). Banking on Africa: can emerging pan-African banks outcompete their global rivals? In Africa's competitiveness in the Global economy (pp. 113-136). Palgrave Macmillan, Cham. Retrieved from https://www.springerprofessional. de/en/banking-on-africa-can- emerging-pan-african-banksoutcompete-thei/15354498

3. Adetiloye, K. A., Adegboye, F B., \& Akinjare, V. A. (2020) Sustainable financial access for female entrepreneurs in the micro, small and medium enterprises sector in Nigeria. Cogent Social Sciences, 6(1), 1823600. https:// doi.org/10.1080/23311886.2020.1 823600

4. Ahmed, H., Mohieldin, M., Verbeek, J., \& Aboulmagd, F. (2015). On the SDGs and the role of Islamic finance. The World Bank.

5. Akinlo, A. E., \& Oni, I. O. (2015). Determinants of bank credit growth in Nigeria 1980-2010. European Journal of Sustainable Development, 4(1), 23-23. https:// doi.org/10.14207/ejsd.2015. v4n1p23

6. Akintoye, V. A., \& Opeyemi, O. A (2014). Prospects for Achieving Sustainable Development through the Millennium Development Goals in Nigeria. European Journal of Sustainable Development, 3(1), 33-33. https://doi.org/10.14207/ ejsd.2014.v3n1p33

7. Aliyu, S. M., \& Bello, G. B. (2013). An assessment of the contribution of commercial banks to the growth of small and medium scale enterprises in Nigeria. International Journal of Research in Social Sciences, 2(4), 47-55. Retrieved from https:// www.semanticscholar.org/ paper/AN-ASSESSMENT-OFTHE-CONTRIBUTION-OF- 
COMMERCIAL-TO-Aliyu-Bello/ be135b73d992fdaa113c9bd3452ae5 acd36354a1

8. Antoniades, A., Widiarto, I., \& Antonarakis, A. S. (2019). Financial crises and the attainment of the SDGs: an adjusted multidimensional poverty approach. Sustainability Science, 15, 1683-1698. https://doi. org/10.1007/s11625-019-00771-Z

9. Babajide, A. A., \& Olokoyo, F. O. (2017). Assessment of Financial Stability in Emerging Economies: Evidence from Nigeria. In Global Financial Crisis and Its Ramifications on Capital Markets (pp. 191-207). Springer, Cham. https://doi.org/10.1007/978-3319-47021-4_15

10. Baranes, A. (2009). Towards Sustainable and Ethical Finance. Development, 52(3), 416420. https://doi.org/10.1057/ dev.2009.47

11. Bebeji, A. (2013). Consolidation and asset quality of banks in Nigeria. International Journal of Business and Management Invention, 2(2), 12-20. Retrieved from http://www.ijbmi.org/papers/ Vol(2)2/Version-1/B221220.pdf

12. Bordon, I., \& Schmitz, B. (2015). Financial stability as a precondition for the financing of sustainable development in emerging and developing countries (Briefing Paper No. 23/2015). German Development Institute. Retrieved from https://www.die-gdi.de/ uploads/media/BP_23.2015.pdf

13. Carree, M.A., Van Stel, A. J., Thurik, A.R., \& Wennekers, S. (2007). The relationship between economic development and business ownership revisited. Entrepreneurship and Regional Development, 19(3), 281-291. Retrieved from https://papers. tinbergen.nl/07022.pdf

14. Cheang, N., \& Choy, I. (2010). Aggregate Financial Stability Index for an Early Warning System. Research and Statistics Department, Monetary Authority of Macao.

15. Duffie, D. (2019). Prone to fail: the pre-crisis financial system. Journal of Economic Perspectives, 33(1), 81-106. https://doi.org/10.1257/ jep.33.1.81

16. Dwumfour, R. A. (2017). Explaining banking stability in Sub-Saharan Africa. Research in International Business and Finance, 41, 260-279. https://doi. org/10.1016/j.ribaf.2017.04.027

17. Egede, T., \& Lee, R. (2007). Bank Lending and the Environment: Not Liability but Responsibility. The Journal of Business Law, 8(1), 868-883. Retrieved from http:// orca.cf.ac.uk/id/eprint/66382

18. Egharevba, M. E. (2007). Restructuring the Nigerian state for sustainable development: The value challenge. IFE Psychologia, 15(2), 143-163. Retrieved from http://eprints.covenantuniversity. edu.ng/id/eprint/579

19. Eke, P. O., Adetiloye, K. A., \& Adegbite, E. O. (2020). An analysis of bond market liquidity and real sector output in selected African economies. E\&M: Economics and Management, 23(4), 166182. https://doi.org/10.15240/ tul/001/2020-4-011

20. Enders, J. C., \& Remig, M. (Eds.) (2014). Theories of sustainable development: An introduction. In Theories of sustainable development. Routledge. https:// doi.org/10.4324/9781315757926

21. Fernández, A. I., González, F., \& Suárez, N. (2016). Banking stability, competition, and economic volatility. Journal of Financial Stability, 22, 101120. https://doi.org/10.1016/j. jfs.2016.01.005

22. Gangi, F., Meles, A., D’Angelo, E., \& Daniele, L. M. (2019). Sustainable development and corporate governance in the financial system: Are environmentally friendly banks less risky? Corporate Social Responsibility and Environmental Management, 26(3), 529-547. https://doi.org/10.1002/csr.1699

23. Grober, U. (2007). Deep roots: A conceptual history of 'sustainable development' (Nachhaltigkeit) (WZB Discussion Papers No. P2007-002). WZB Berlin Social
Science Center. Retrieved from https://www.econstor.eu/handle/10419/50254

24. Haigh, M. (2012). Publishing and defining sustainable finance and investment. Journal of Sustainable Finance \& Investment, 2(2), 88-94. Retrieved from https://www.tandfonline.com/doi/abs/10.1080/2043 0795.2012.688797

25. Ingves, S. (2016). Implementing the Regulatory Reform Agenda: The Pitfall of Myopia. In The New International Financial System: Analyzing the Cumulative Impact of Regulatory Reform (pp. 37-46). https://doi. org/10.1142/9789814678339_0002

26. Jaiyesimi, R. (2016). The challenge of implementing the SDGs in Africa: The way forward. African Journal of Reproductive Health, 20(3), 13-18. Retrieved from http://www.bioline.org.br/ pdf?rh16029

27. Jayakumar, M., Pradhan, R. P., Dash, S., Maradana, R. P., \& Gaurav, K. (2018). Banking competition, banking stability, and economic growth: Are feedback effects at work? Journal of Economics and Business, 96(3), 15-41. https://doi.org/10.1016/j. jeconbus.2017.12.004

28. Jeucken, M. (2001). Sustainable finance and banking: The financial sector and the future of the planet (pp. 23-57). London: Earthscan Publications Ltd.

29. Johansen, S. (1991). Estimation and Hypothesis Testing of Cointegration Vectors in Gaussian Vector Autoregressive Model. Econometrica, 59(6), 1551-1580. https://doi.org/10.2307/2938278

30. Kharas, H., Prizzon, A., \& Rogerson, A. (2014). Financing the post-2015 Sustainable Development Goals: A rough roadmap. Overseas Development Institute, London. Retrieved from https://cdn.odi. org/media/documents/9374.pdf

31. Kutpsoyiannis, A. (1997). Theory of Econometrics. Hampshire Macmillan Press Ltd.

32. Liew, V. K.-S. (2004). Which lag length selection criteria should we employ. Economics Bulletin, 3(33), 
1-9. Retrieved from http://www. accessecon.com/pubs/EB/2004/ Volume3/EB-04C20021A.pdf

33. Noor, Z., \& Pickup, F. (2017). The role of Zakat in supporting the SDGs. Baznas and UNDP Brief Series.

34. Novotny-Farkas, Z. (2016). The interaction of the IFRS 9 expected loss approach with supervisory rules and implications for financial stability. Accounting in Europe, 13(2), 197-227. https:// doi.org/10.1080/17449480.2016.1 210180

35. Nwachukwu, P. O. (2014). Funding education for sustainable development in Nigeria: Challenges and the way forward. Journal of Education and Practice, 5(20), 51-56. Retrieved from https://www.iiste.org/Journals/index.php/JEP/article/view/14243

36. Oke, M. O., \& Aluko, O. A. (2015). Impact of commercial banks on small and medium enterprises financing in Nigeria. IOSR Journal of Business and Management, 17(4), 23-26. Retrieved from http://www.iosrjournals.org/iosrjbm/papers/Vol17-issue4/Version-1/D017412326.pdf

37. Okey, N., Precious, O., \& Onyema, J. I. (2019). Financial soundness of deposit money banks in Nigeria: The camels model approach. Journal of Finance and Marketing, 3(1), 1-8. Retrieved from https:// www.alliedacademies.org/articles/ financial-soundness-of-depositmoney-banks-in-nigeria-thecamels-model-approach.pdf

38. Olawumi, S. O., Lateef, L. A., \& Oladeji, E. O. (2017). Financial deepening and bank performance: A case study of selected commercial banks in Nigeria. Journal of Mathematical Finance, 7(3), 519-535. https://doi. org/10.4236/jmf.2017.73028

39. Oleribe, O. O., \& Taylor-Robinson, S. D. (2016). Before SDGs (SDG): why Nigeria failed to achieve the millennium development goals (MDGs). The Pan African Medical Journal, 24(2), 1545. https://doi.org/10.11604/ pamj.2016.24.156.8447
40. Osabohien, R., Adeleye, N., \& De Alwis, T. (2020). Agro-financing and food production in Nigeria. Heliyon, 6(5), 40-55. https://doi. org/10.1016/j.heliyon.2020.e04001

41. Ozili, P. K. (2018). Banking stability determinants in Africa. International Journal of Managerial Finance, 14(4), 462-483. Retrieved from https://ideas.repec.org/a/ eme/ijmfpp/ijmf-01-2018-0007. html

42. Ozili, P. K. (2019). Determinants of Banking Stability in Nigeria (MPRA Paper No. 94092). Retrieved from https://mpra.ub.uni-muenchen. de/94092/

43. Pesaran, M. H., \& Shin, Y. (1998). An autoregressive distributed-lag modelling approach to cointegration analysis (pp. 371-413). Cambridge University Press. https://doi. org/10.1017/CCOL521633230.011

44. Pesaran, M. H., Shin, Y. \& Smith, R. J. (2001). Bounds testing approaches to the analysis of level relationships. Journal of Applied Econometrics, 16(3), 289-326. https://doi.org/10.1002/jae.616

45. Pesaran, M. H., Shin, Y., \& Smith, R. P. (1999). Pooled mean group estimation of dynamic heterogeneous panels. Journal of the American Statistical Association, 94(446), 621-634. Retrieved from https://www.tandfonline.com/doi/ abs/10.1080/01621459.1999.104 74156

46. Pisano, U., Martinuzzi, A., \& Bruckner, B. (2012). The financial sector and sustainable development: Logics, principles and actors (ESDN Quarterly Report No. 27). European Sustainable Development Network. Retrieved from https://www.esdn.eu/fileadmin/ESDN_Reports/2012-December-The_Financial_Sector_and_ Sustainable_Development.pdf

47. Sadiq, R., \& Mushtaq, A. (2015). The role of Islamic finance in sustainable development. Journal of Islamic Thought and Civilization, 5(1), 46-65. http://admin.umt.edu. pk/Media/Site/UMT/SubSites/jitc/ FileManager/JITC\%20Spring\%20 2015/04-Role\%20of\%20Islamic\%20Financial\%20Institutions.pdf
48. Sere-Ejembi, A., Udom, I. S., Salihu, A., Atoi, N. V., \& Yaaba, B. N. (2014). Developing banking system stability index for Nigeria. CBN Journal of Applied Statistics, 5(1), 49-77. Retrieved from https://www.econstor.eu/bitstream/10419/144780/1/861766113. pdf

49. Shijaku, G. (2016). Banking stability and its determinants: A sensitivity analysis on methodological changes. The Economic Review, 3(1), 18-30.

50. Soludo, C. C. (2004).

Consolidating the Nigerian banking industry to meet the development challenges of the 21 st century. BIS Review, 43, 1-6. Retrieved from https://www.bis. org/review/r040727g.pdf

51. Stenberg, K., Hanssen, O., Edejer, T. T. T., Bertram, M., Brindley, C., Meshreky, A., Rosen, J. E., Stover, J., Verboom, P., Sanders, R., \& Soucat, A. (2017). Financing transformative health systems towards achievement of the health SDGs: a model for projected resource needs in 67 low-income and middle-income countries. The Lancet Global Health, 5(9), 875-887. https://doi.org/10.1016/ S2214-109X(17)30263-2

52. Thompson, P., \& Cowton, C. J. (2004). Bringing the Environment into Bank Lending: Implications for Environmental Reporting. The British Accounting Review, 36(2), 197-218. https://doi.org/10.1016/j. bar.2003.11.005

53. Thomson, J. B. (1992). Modelling the bank regulator's closure option: a two-step logit regression approach. Journal of Financial Services Research, 6(1), 5-23. Retrieved from https://link. springer.com/article/10.1007/ BF01046114

54. Toader, T., Onofrei, M., Popescu, A. I., \& Andrieș, A. M. (2018). Corruption and banking stability: Evidence from emerging economies. Emerging Markets Finance and Trade, 54(3), 591-617. https://doi.org/10.1080/154049 6X.2017.1411257

55. United Nations. (2014). Report of the Intergovernmental Committee 
of Experts on Sustainable Development Financing. New York. Retrieved from https://www. un.org/esa/ffd/wp-content/uploads/2014/12/ICESDF.pdf

56. United Nations. (2015). Outcome document of the Third International Conference on Financing for Development: Addis Ababa Action Agenda. New York. Retrieved from https:// www.un.org/africarenewal/sites/ www.un.org.africarenewal/files/ N1521991.pdf

57. Usman, A. S., \& Tasmin, R. (2016). The Relevance of Islamic Micro-finance in achieving the Sustainable Development Goals. International Journal of Latest Trends in Finance and
Economic Sciences, 6(2), 11151125. Retrieved from https:// www.um.edu.mt/library/oar/ bitstream/123456789/72132/1/ The_relevance_of_islamic_micro_ finance_in_achieving_the_sustainable_development_goals.pdf

58. Weber, O. (2014). The financial sector's impact on sustainable development. Journal of Sustainable Finance \& Investment, 4(1), 1-8. https://doi.org/10.1080/2 0430795.2014 .887345

59. Weber, O., Scholz, R. W., \& Michalik, G. (2010). Incorporating sustainability criteria into credit risk management. Business Strategy and the Environment 19(1), 39-50. https://doi. org/10.1002/bse.636
60. Wiek, A., \& Weber, O. (2014). Sustainability challenges and the ambivalent role of the financial sector. Journal of Sustainable Finance \& Investment, 4(1), 9-20. https://doi.org/10.1080/20430795 2014.887349

61. Ziolo, M., Ghoul, M. B. G. B., \& Aydın, H.İ. (2018). Financial stability vs. sustainable development and its financing. In Regaining Global Stability after the Financial Crisis (pp. 88-107). IGI Global. Retrieved from https://www.igi-global.com/ chapter/financial-stability-vssustainable-development-and-itsfinancing/202072 